\title{
The spatial agglomeration of the labor manufacturing industry in Central Java Province, 2005-2015
}

\section{(Aglomerasi spasial industri manufaktur tenaga kerja di Provinsi Jawa Tengah, 2005- 2015)}

\author{
Muhammad Izzudin*1, Su Ritohardoyo**, Lutfi Muta'ali** \\ * Universitas Sriwijaya, Jl. Raya Palembang-Prabumulih Km. 32 Indralaya, Ogan Ilir, Sumatera \\ Selatan, 30662, Indonesia \\ ** Universitas Gadjah Mada, Jl. Kaliurang, Bulaksumur, Yogyakarta, 55281, Indonesia \\ ${ }^{1}$ Corresponding author, Surel: muhammadizzudin@fisip.unsri.ac.id
}

Paper received: 04-02-2021; revised: 18-06-2021; accepted: 27-07-2021

\begin{abstract}
The number of industries in Central Java is expanding, resulting in an improvement in the area's economy. The study's objectives are as follows: (1) to examine the dynamics of manufacturing labor; (2) to examine the spatial concentration of manufacturing industry activity; and (3) to analyze variables impacting industrial sector employment. Between 2005 and 2015, this quantitative study analyzed secondary data. The descriptive analysis, time series analysis, Klassen typology analysis, industry index analysis, and multiple linear regression techniques were employed to accomplish the research objectives. The study's findings are as follows: (1) the number of industries has decreased, particularly since 2007, from 6.9 percent in 2007 to 4.8 percent in 2015; (2) the spatial concentration of the manufacturing industry in Central Java is concentrated in 11 regions: Sukoharjo, Karanganyar, Kudus, Semarang, Semarang City, Purbalingga, Salatiga, Tegal, Temanggung, Pekalongan, and Pekalongan City; and (3) wage is the most important factor in the absorption of industrial labor in Central Java Province. The findings of this study also contribute to the development of economic Geography learning materials by focusing on the growth of an area driven by the manufacturing industry.
\end{abstract}

Keywords: industry; agglomeration; spatial concentration industry; labor

\section{Introduction}

Economic geography research about industrial agglomeration and urbanization is still quite insignificant. Globalization and urbanization have influenced economic and industrial activity across the country (He, Mao, \& Zhu, 2018). When it comes to creating large cities on a national scale, the industry becomes an important factor (Busch, Foxon, \& Taylor, 2018). Manufacturers are a substantial industrial development, enormous industry, large-scale processing, and rich information and technology that is currently a trend following the formation of a metropolitan city's economic expansion (Latif, Gopalakrishnan, Nimbarte, \& Currie, 2017; A. K. W. Lau, Lee, \& Cheng, 2018; Wu \& Yang, 2018).

The manufacturing industry has increasingly become the focus of empirical studies by national and international academics simultaneously, with labor capital and technology transfer both playing significant roles. Since the 1950s, the world has already seen four great scales of industrial growth and worldwide transfer of technology, most of which have benefited the regional industrial structure by improving and strengthening it (Carvalho, Chaim, Cazarini, 
\& Gerolamo, 2018; Kornfeld \& Kara, 2015; B. Wang, 2018). Industrial agglomeration is an inherent consequence of industrial development, especially in developing countries (Cainelli, Ganau, \& Giunta, 2018; Drucker \& Feser, 2012; Mori \& Smith, 2015). Industrial agglomeration expansion also contributes considerably to growth in the economic center and periphery. As a result, these elements are critical for bringing economic growth forward as well (Athukorala \& Narayanan, 2018).

A geographic concentration and agglomeration research it is critical to conduct an industrial business analysis. It was because the geographical concentration demonstrates a region's contribution and the dispersion of an industry's locations. Due to an unequal geographical distribution dominated by industrial regions, it is reasonable to presume that a specific industry is spatially concentrated in that region (Asheim, Grillitsch, \& Trippl, 2016; Asheim, Isaksen, \& Trippl, 2019). Considering studying the economy from a geographic perspective, the most crucial component is the spatial agglomeration of industries (McCann \& Van Oort, 2019; You \& Bie, 2017). According to competitive industry theory, the industry prefers to locate in areas with other relevant industrial clusters, such as textiles, logistics, food, and beverages, in attempt to develop a profitable rivalry for the expansion of industrial clusters in the region (Sosnovskikh, 2017), including economies of scale, technology advancements, industrial specialization, and expenditure (Taddeo, Simboli, Ioppolo, \& Morgante, 2017).

Due to the rising importance of urban agglomeration and the complexity of internal and external elements, the government needs a systematic planning strategy for the coordinated development of urban agglomerations. It describes spatial integration in urban agglomerations in detail and examines the correlation between spatial integration and the growth of industrial enterprises in this environment. Despite the reality that urban agglomeration has been the subject of lot research focused on its conceptualization (Fang \& Yu, 2017), spatial structures (Guo \& He, 2017; Zhen, Cao, Qin, \& Wang, 2017), development technique (Liu, Zhang, Kong, Wang, \& Chen, 2018; Shao, Tian, \& Yang, 2017). There is a scarcity of research on these two issues at the moment. First, the metropolitan system is analyzed from a network perspective, employing data on intercity transportation trends. While the methodologies and research associated with the network paradigm are efficient in highlighting the process of global urban system construction (Meijer \& Bolívar, 2016). As a result, it denies direct contact between cities and is unable to quantify industry-specific patterns and geographical expansion. Furthermore, it stops desperately deficient in identifying key issues such as development strategies, political intervention, and cultural identity. Second, the manufacturing industry, like urban and regional development, is always expanding, developing, and increasing (Pike, Rodríguez-Pose, \& Tomaney, 2017; Wang, Lin, Glendinning, \& Xu, 2018). The linkage between spatial integration and industrial growth characteristics (e.g., specialization, differentiation, and competition), as well as their influence on the creation and evolution of urban agglomerations, remain unclear.

This study provides contributes to a more complete knowledge of spatial integration and industrial agglomeration's development. This contribution might potentially be used to enrich economic geography teaching and learning. In a conclusion, this study aims to overcome the fundamental gap by analyzing how the concept of geographical concentration of the manufacturing industry in Central Java arises. More specifically, this study aims to accomplish three goals: (1) understanding the dynamics of Central Java's labor manufacturing industry, (2) examining the spatial agglomeration pattern of the labor manufacturing industry in Central Java Province, and (3) predicting the most impacted variables absorb industrial employment. 
Jurnal Pendidikan Geografi:

Kajian, Teori, dan Praktik dalam Bidang Pendidikan dan Ilmu Geografi

27(1), 2022, 38-50

The findings of this study could provide some recommendations for developing a laborintensive industry and providing precise policy guidance on the distribution of new industries in Central Java Province.

\section{Methods}

Industrial agglomeration is measured using a variety of parameters, including industrial concentration, the Gini coefficient, and the location quotient (LQ). Davis and Hashimoto (2018) was analyzing industrial concentration, researchers may examine the link between industrial distribution and economic growth in two nations. Lau, Koo, and Dwyer (2017) argue that deploying only one approach will result in incorrect measurements and will neglect industry demands, possibly reducing heterogeneity caused by the effect of the obtained data, in response, they used a combination of the Gini index and spatial concentration to evaluate the manufacturing industry's geographical distribution. Zheng and Lin (2018) explain the characteristics of industrial agglomeration in their study using the location quotient (LQ).

This study was conducted using secondary data from the Central Java Statistics Agency for the years 1995 until 2015. The data used for this study included the combination of pooled time series and cross-sectional data on industrial employees, the number of companies, gross domestic product (GDP), wages, investments, output values, imports and exports, and taxes. The data analysis techniques used to resolve the question formulation and achieve the objectives are: (1) To analyze and understand the dynamics of labor patterns through time (development trends) in the manufacturing industry, distribution tables and data charts/charts were employed. This distribution table and graph will summarize or illustrate the trend in industrial employees, the number of firms and industrial workers' wages; (2) Analysis to determine industrial spatial concentration using two analytical techniques: industrial development typology based on the Klassen typology and industry specialization index, which will be processed using ArcGIS 10.3 software. The complete formula can be seen in Table 1.

Table 1. Industrial development typology

\begin{tabular}{lll}
\hline $\begin{array}{l}\text { Contribution }(y) \\
\text { Growth }(r)\end{array}$ & $(y \mathrm{GDRP}>y \mathrm{GDRP})$ & $(y \mathrm{GDRP}<y \mathrm{GDRP})$ \\
\hline$(r \mathrm{Lbi}>r \mathrm{Lb})$ & Developed and Fast-Growing Industry & Fast Developing Industry \\
$(r \mathrm{Lbi}<r \mathrm{Lb})$ & (DFGI) & (FDI) \\
\hline
\end{tabular}

Explanation:

yGDRPi > yGDRP : The GDRP of the industrial sector in the Regency is greater than the GDRP of the province

yGDRP $<$ yGDRP : The GDRP of the industrial sector in the Regency is smaller than the GGDRP of the province

rLbi $>$ rLbk : The number of laborers in the district industrial sector is greater than the number of workers in the province

$\mathrm{rLbi}<\mathrm{rLb} \quad:$ The number of laborers in the district industrial sector is smaller than the number of laborers in the province 
Formulation:

GRDP Contribution (y)

$\mathrm{y}=\frac{\text { GDRPi regency }}{\text { GDRPi province }} \times 100 \%$

Labor growth $(r)$

$\mathrm{r}=\left(\frac{L b 2015}{L b 2010} \times \frac{1}{n-1}\right) \times 100 \%$

\section{Source: Muta'Ali (2015) (modification)}

The Specialization Index measures the spatial concentration of manufacturing in province $i$ in year $t$. The specialization index is used to describe the agglomeration of manufacturing industries. This index is calculated using data on Large and Medium Industries (IBS) by Central Java Central Bureau of Statistics. Below is the formula used:

$$
\text { IS }=\frac{\left(\frac{E i j}{\sum E i j}\right)}{\left(\frac{\sum \sum i j i j}{\Sigma \Sigma j E i j}\right)}
$$

Explanation:

$\begin{array}{ll}\text { Eij } & : \text { Labor sector } \mathrm{i} \text { in region } \mathrm{j} \\ \sum \text { Eij } & : \text { Total labor sector } \mathrm{i} \text { in region } \mathrm{j} \\ \sum \mathrm{j} \text { Eij } & : \text { Labor in region } \mathrm{j} \\ \sum \sum \mathrm{j} \text { Eij } & : \text { Total labor in region } \mathrm{j}\end{array}$

Source: Kuncoro and Wahyuni (2009)

Analysis of the relationship between labor and independent variables using Pearson Product Moment Correlation and Multiple Linear Regression to estimate the prediction/ impact. Multiple Regression analysis techniques is one type of statistical testing method used to determine the factors that influence a dependent variable. The statistical test to be carried out is to determine the magnitude of the influence of the independent variable (influence variable) consisting of the variable (1) wages (rupiah), (2) industrial investment value (rupiah), (3) number of industrial units (unit), (4) tax value (rupiah). The statistical correlation and multiple linear regression were tested using SPSS 22 software (Statistical Program for Social Science). The formula used is as follows:

$Y=\alpha+b 1 x 1+b 2 x 2+c 3 x 3+d 4 x 4$

Explanation:

$\begin{array}{ll}\mathrm{Y} & : \text { Number of industrial labor (million people) } \\ \alpha & : \text { Constant } \\ \mathrm{b} 1, \mathrm{~b} 2, \mathrm{b3}, \mathrm{b} 4 & : \text { Regression coefficient value } \\ \mathrm{x} 1 & : \text { Total industrial labor wages (billion rupiah) } \\ \mathrm{x} 2 & : \text { Industrial investment value (billion rupiah) } \\ \mathrm{x} 3 & : \text { Number of companies (unit) } \\ \mathrm{x} 4 & : \text { Tax value (billion rupiah) }\end{array}$




\section{Result and Discussion}

\subsection{Labor Dynamics of Manufacturing Industry}

From 1995 and 2015, the number of industrial employees increased by 3.8 percent, from 3.6 percent to 6.4 percent. Although the number of industrial employees in Central Java has continued to bounce up and down throughout this period, the graph shows a general upward trend. Indonesia was experiencing a monetary crisis at the time, which was documented here (Kristianto \& Nurcahyo, 2020). There has been no drop in the number of industrial employees between 1997 and 2003 (Figure 1), while there has been a slight gain, precisely only 0.3 percent, ranging from 4 percent to 4.4 percent.

Wages for industrial employees have increased steadily over 20 years, from 0.5 percent in 1995 to 10.9 percent in 2015, a total of 11.4 percent. In the manufacturing sector, one of the causes for the industry's collapse has been the high pay paid to employees. Corporations that wish to continue to exist would strive to maximize their earnings, according to corporate behavior theory (Arsyad, 2015; Kennedy, 2017; Siregar et al., 2021). Afterward, variables such as profit prospects and the expansion of the industry will serve as an incentive for people to work in specific industries (Figure 1).
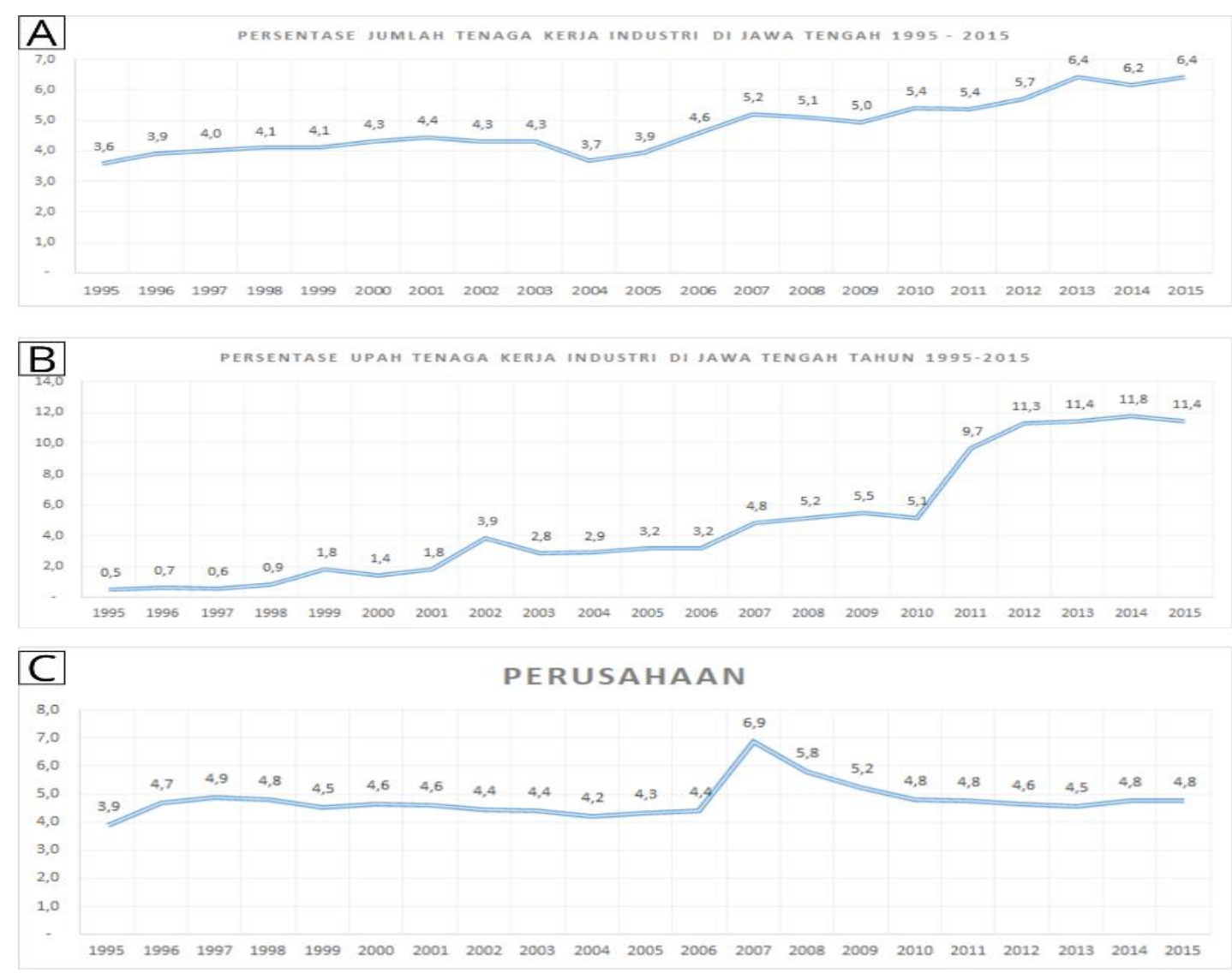

Figure 1. (A) Industrial Workforce Percentage Graph, (B) Industrial Labor Wages, and (C) Number of Industries in Central Java Province in 1995-2015 Period 
Look at the economy over 20 years and it can be seen that it is still stable, with the number of companies remaining at around 3.9 percent and increasing by 10 percent each year until the country experienced a monetary crisis in 1998. Which resulted in a large number of foreign companies abandoning Indonesia (Budiyanti, 2016), because the political situation in 1998 was negative for business investment (Kumala \& Rostiana, 2018). Immediately following the monetary crisis in 1998, the number of enterprises decreased to between 4.2 and 4.5 percent, i.e., between 1999 and 2006 (Figure 1). The industrial sector in Central Java witnessed a surge of up to 6.9 percent in 2007 , but the figure declined again the following year, remaining at about 4.8 percent in 2015, the same as in 1998.

\subsection{Spatial Concentration of Manufacturing Industry}

Overall, only four districts, namely Karanganyar Regency, Kudus Regency, Semarang Regency, and Kendal Regency, were classified as Developed and Fast-Growing Industry (DFGI). A significant number of labor expansions in these four districts has been observed, with the number above the provincial average. Furthermore, the contribution to the regional economy is substantial, particularly evidenced by the proportion of the industrial sector's contribution to the district's Gross Domestic Regional Product (GDRP) that exceeds the provincial level. Besides it, three of these four districts are in adjacent areas. Kendal Regency, Semarang Regency, and Kudus Regency are areas on the north coast whose territories border each other. These three areas in Central Java have also become industrial hubs. To put it another way, the district's industrial sector has become a driving force behind regional economic growth.

Several international firms have developed new factories in Purbalingga Regency, Salatiga City, and Tegal City, which are classified in the Fast-Developing Industry category. An example of this is the tailpipe industry in Purbalingga (Putri, 2019; Saputra \& Budiani, 2017), which involves foreign investment in the hair and artificial hair business (Setyoningrum, 2017).

Only one district is classified as Developed and Depressed Industry (DDI) because the value of industry is higher than the provincial average. It has made a significant contribution to the regional economy. There is, however, a tendency for the growth of the number of workers to be moderate. This demonstrates that the industrial sector's labor absorption is still not ideal, but the added value of the industrial sector's contribution is rather high. According to Fatmawati and Utomo (2017) study, the manufacturing industry in Sukoharjo Regency is based on the establishment of the basic and chemical, metal, and micro industries.

Rapidly Developing Industries are found in the majority of districts and cities in Central Java, according to an examination of industrial growth by the Klassen Typology. This indicates that the industrial sector's rise in labor has a high value. In contrast, the industrial sector has not had a considerable impact on the area economy or gross domestic product (GDP). DFGIclassified regions and cities tend to be located in the northern region or along the north coast of the country. Manufacture industry in Central Java represent in Table 2. Spatial Concentration of manufacture industry in central java show that Semarang Regency and Kudus Regency are well-known for their industrial growth. 
Jurnal Pendidikan Geografi:

Kajian, Teori, dan Praktik dalam Bidang Pendidikan dan Ilmu Geografi

27(1), 2022, 38-50

Table 2. Spatial Concentration of Manufacturing Industry in Central Java

\begin{tabular}{lll}
\hline No & Regency / Cities & Industrial Development Typology \\
\hline 1 & Sukoharjo Regency & Developed and Depressed Industry (DDI) \\
2 & Karanganyar Regency & Developed and Fast-Growing Industry (DFGI) \\
3 & Kudus Regency & Developed and Fast-Growing Industry (DFGI) \\
4 & Semarang Regency & Developed and Fast-Growing Industry (DFGI) \\
5 & Purbalingga Regency & Fast Developing Industry (FDI) \\
6 & Salatiga City & Fast Developing Industry (FDI) \\
7 & Tegal City & Fast Developing Industry (FDI) \\
8 & Temanggung Regency & Undeveloped Industry (UI) \\
9 & Pekalongan Regency & Undeveloped Industry (UI) \\
10 & Semarang City & Undeveloped Industry (UI) \\
11 & Pekalongan City & Undeveloped Industry (UI) \\
\hline
\end{tabular}

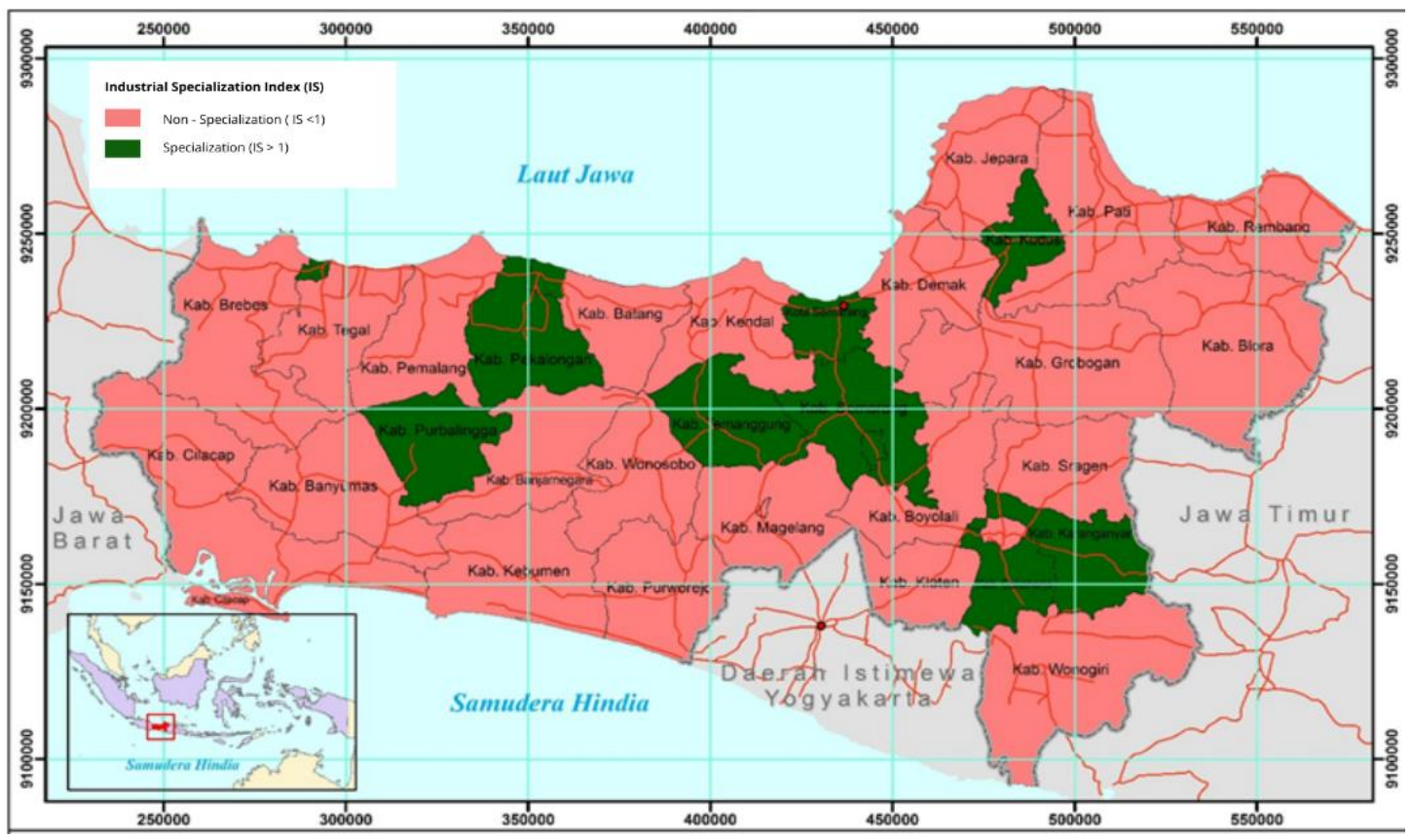

Figure 2. Spatial Concentration Maps in Central Java Using Industrial Specialization Index

The findings of the Specialization Index calculation reveal that the province of Central Java has eleven districts/cities with an IS score greater than one (Figure 2). As a result, the eleven regions/cities can be categorized as industrialized. More jobs can be created through a geographical concentration of industrial agglomerations rather than by Central Java's proportion of industry itself.

In their research conducted throughout Java, Nugroho and Wahyuni (2019) discovered that there were eleven regions in Central Java that were agglomerated using the Hoover Balassa Index (HBI) method, which were namely Purbalingga Regency, Boyolali Regency, Sukoharjo Regency, Karanganyar Regency, Pati Regency, Kudus Regency, Demak Regency, Regency Semarang, Salatiga City, Semarang. Only three district regencies were used for the Klassen typology technique, namely Temanggung Regency, Pekalongan Regency, and Pekalongan City. Three different regencies were used for the HBI method, there are Boyolali Regency, Pati Regency, and Demak Regency. 


\section{Jurnal Pendidikan Geografi:}

\section{Kajian, Teori, dan Praktik dalam Bidang Pendidikan dan Ilmu Geografi}

$$
27(1), 2022,38-50
$$

Six regencies/cities are located in or near the northern shore of Central Java. Kudus Regency, Semarang Regency, Semarang City, Pekalongan Regency, Pekalongan City, and Tegal City all share a northern coast region. These six regencies can be considered an agglomeration, implying that they have developed into industrial growth centers as a result of their industry specialization. This can also be witnessed in Salatiga City's industrial growth, which is located near Semarang Regency. This situation also has an effect on the potential for industrial development and, more broadly, on the possibility of quicker economic growth. Industrial growth also has the potential to increase the number of industrial laborers.

The districts of Karanganyar, Kudus, and Semarang have a concentration of industry, which is typologically developed and growing rapidly because the number of industrial workers and gross domestic regional product (GDRP) is far greater than the number of workers and the amount of GDRP in the rest of the region. Because of the presence of this industrial concentration, more and more people are migrating to these three areas. The determinants of urbanization associated with migration have also been investigated by Wang et al., (2017); Day and Xia (2019), Chandrasekhar and Sharma (2015) in India, Green (2018) in Nigeria, Awumbila (2017) in Kenya.

There are three districts where industry is concentrated in areas with fast-growing industrial categories (labor intensive). These are Purbalingga Regency, Salatiga Regency, and Tegal Regency. Purbalingga Regency has the highest concentration of industry in the country. The features of the industry in these three districts are that the number of industrial employees outnumbers the number of workers in other sectors, so that it can be stated that appropriate human resources are the most important capital for growth.

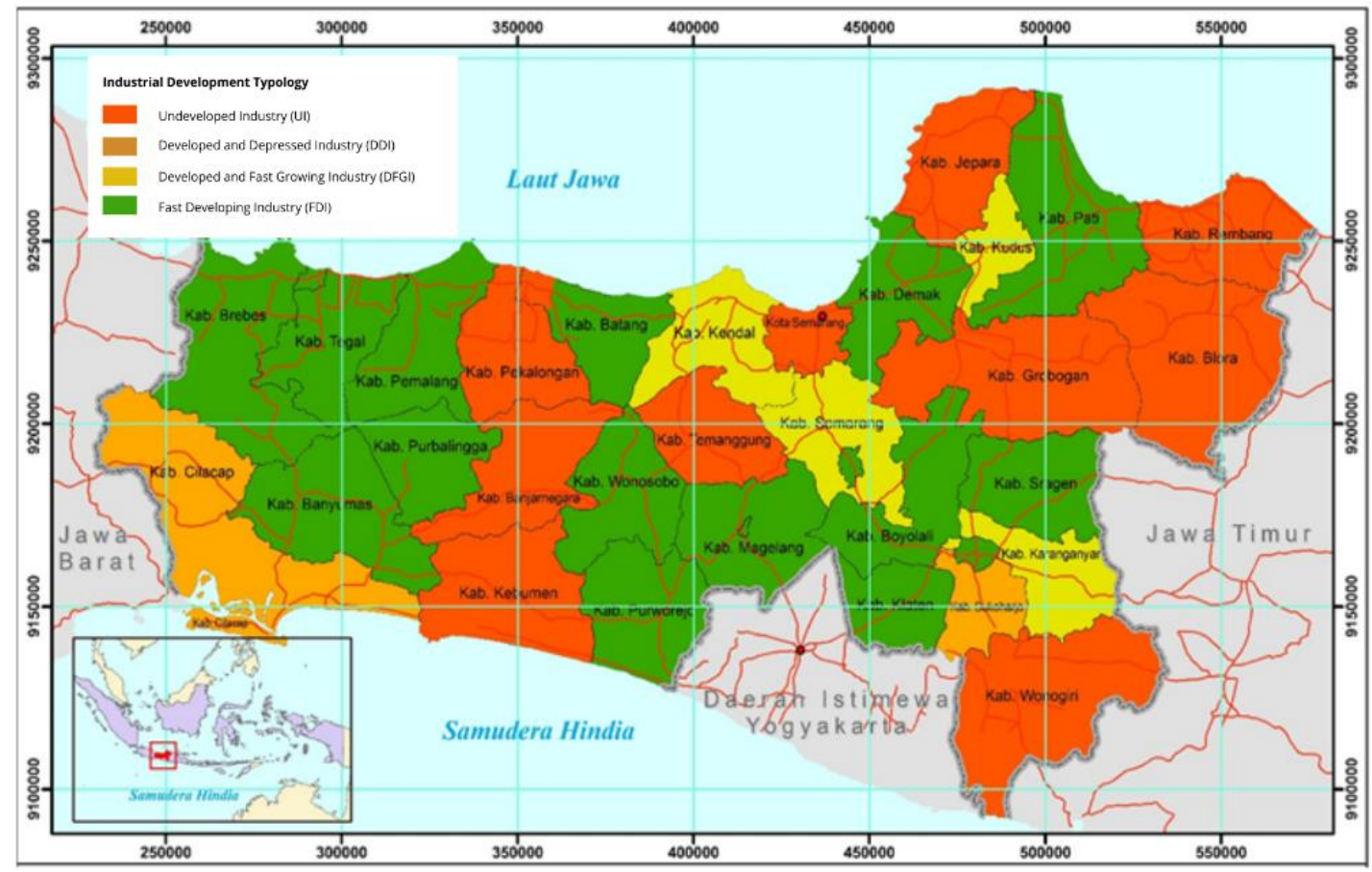

Figure 3. Industrial Development Typology Maps in Central Java Using Klassen Typology

The noteworthy point is that manufacturing industries are spatially concentrated in districts with relatively lagging industrial typologies. Semarang City, Pekalongan City, 
Jurnal Pendidikan Geografi:

Kajian, Teori, dan Praktik dalam Bidang Pendidikan dan Ilmu Geografi

27(1), 2022, 38-50

Pekalongan Regency, and Temanggung Regency are the districts (Figure 3). While the average increase of the industrial workforce exceeds the growth of the workforce in these four districts, the number of industrial employees remains smaller than the total workforce in the districts.

\subsection{Factors of Absorption of Industrial Labor}

The greatest correlation between employment and earnings in Central Java is 0.945 for industrial employees. The second component is investment, which has a correlation coefficient of 0.916 , and the third element is industrial taxation, which has a correlation coefficient of 0.853. The findings of this statistical test support Manyika et al., (2017) and Sumarsono's (2009) argument that labor demand is connected to the number of workers required by a particular economic sector. The level of wages, the value of output, and investment all have an effect on labor absorption. Changes in these variables will have an effect on the number of workers absorbed by a particular industry.

Taxes that enter areas also serve as a catalyst for the easing of laws on labor migration to the region, as the correlation value is 0.853 , indicating a clear benefit to the region that is the investment destination (Table 3). What's remarkable is that this industry's absorption is not directly proportional to the number of enterprises in the area with the lowest correlation, 0.464. This implies that only a few large-scale enterprises in Central Java absorb manpower, mainly the tobacco and textile industries.

Furthermore, based on Table 4, the regression equation between the absorption of industrial workers with the four variables namely salary, investment, number of industries and industrial taxes can be described as follows:

$Y=1,838+0,554 X_{1}+0,275 X_{2}+0,011 X_{3}+0,193 X 4$

Where:

Y : Number of Industrial Labor (Million people)

$\mathrm{x} 1 \quad$ : Total Industrial Labor wages (Billion rupiah)

$\mathrm{x} 2$ : Industrial Investment Value (Billion rupiah)

x 3 : Number of companies (unit)

$\mathrm{x} 4$ : Tax value (Billion rupiah)

Table 3. Pearson Product Moment Correlation

\begin{tabular}{lll}
\hline \multirow{2}{*}{ Independent Variable } & \multicolumn{2}{l}{ Dependent variable: Industrial Labor } \\
\cline { 2 - 3 } & Significant (1-tailed) & Correlation value \\
\hline Wages & 0,000 & 0,945 \\
Investment & 0,000 & 0,916 \\
Number of Industries & 0,002 & 0,464 \\
Tax & 0,000 & 0,853 \\
\hline
\end{tabular}

Source: SPSS analysis (2019) 
Jurnal Pendidikan Geografi:

Kajian, Teori, dan Praktik dalam Bidang Pendidikan dan Ilmu Geografi

$27(1), 2022,38-50$

Table 4. Coefficients Value of Labor Absorption Testing Results

\begin{tabular}{llllll}
\hline \multirow{2}{*}{ Variabels } & $\begin{array}{l}\text { Unstandardized } \\
\text { Coefficients }\end{array}$ & $\begin{array}{l}\text { Standardized } \\
\text { Coefficients }\end{array}$ & t & Sig. \\
\cline { 2 - 3 } & $\mathrm{B}$ & Beta & & 0,564 & 0,418 \\
\hline Constant & 1,838 & 0,554 & 6,333 & 0,000 \\
Wages & 0,300 & 0,275 & 2,839 & 0,008 \\
Investment & 0,001 & 0,011 & 0,226 & 0,822 \\
Number of & 0,004 & 0,193 & 2,476 & 0,019 \\
Industries & 0,031 & & & \\
Tax & &
\end{tabular}

Source: SPSS analysis (2019)

The wage beta coefficient of 0.554 indicates that for every additional wage of Rp. 2,392, 1 additional manpower will be provided for the manufacturing industry in Central Java, resulting in a reduction of unemployment to 1 million people, an additional salary or salary allocation of Rp. 2,392 billion annually. This condition indicates that the company's workforce absorption is impacted by the pay rise given, which must be in compliance with the Central Java Province's regional minimum wage.

The growth in industrial employees in Central Java is consistent with a study conducted by Dina (2015) in West Sumatra Province and Rakhmawati and Boedirochminarni (2018) in Gresik. However, the findings of this study differ from those of Nugroho and Wahyuni (2019) who used the static panel method to explain that the existence of a high wage for industrial workers in Java is viewed as a burden that must be borne by the company, such that the higher the wage rate, the higher the wage rate will be, and the smaller the proportion of profits enjoyed by the company. Similarly, Azhari (2019) study in West Java and Rosyana and Soelistyo (2020) research in East Java indicate that the provincial minimum wage has a negative association with employment growth.

The growth in the value of investment in the region dispersed by manufacturing businesses also has an effect on the absorption of a large number of workers, specifically a Rp. 2,113 billion investment funds to attract 1 million industrial workers within a year. This study replicates the findings of Sholihah, Syaparuddin, and Nurhayani (2017); Kusumaningrum (2017) in Indonesia; Yogi (2018) in West Sumatra; and Ginting (2021) in Malang. It is, however, distinct from South Sulawesi, where investment does not contribute to labor absorption (Zulkifli, 2016).

Additional industries also have an effect on employment, as demonstrated by Siregar (2018) that research in the Deli Serdang Regency and Rosyana and Soelistyo (2020) that research in East Java. Additionally, the Province of Central Java benefits from the existence of industry since it generates a tax of Rp. 2.031 billion for every extra 1 million industrial workers. This finding contrasts with Ermansyah and Mahi (2019) finding that corporate income tax (CIT) is not a significant factor for businesses when determining the number of employees.

\section{Conclusion}

This study demonstrates how the dynamics of the industrial workforce changed significantly between 1995 and 2015, during which time salaries, the value of GDP, the value of exports and imports, the value of investment, and the products produced by the industry all increased, while the number of industries decreased. In a result of this condition, the spatial 
Jurnal Pendidikan Geografi:

Kajian, Teori, dan Praktik dalam Bidang Pendidikan dan Ilmu Geografi

27(1), 2022, 38-50

concentration pattern of the manufacturing industry workforce does not form a clumped spatial pattern, but rather a random spatial pattern in eleven districts, including Sukoharjo, Karanganyar, Kudus, Semarang Regency and City, Purbalingga, Salatiga (Pekalongan Regency and City), Tegal, and Temanggung. However, it should be noted that the highest level of industrial employment in Central Java is a result of the salaries supplied by manufacturing enterprises, which differs from area to region. The result of this study also contributes to supporting the learning material development of economic Geography, by focusing on the development of an area that is driven by the manufacturing industry.

\section{References}

Arsyad, L. (2015). Konsep dasar ekonomika industri. Jakarta: UT.

Asheim, B. T., Grillitsch, M., \& Trippl, M. (2016). Regional innovation systems: Past-present-future. In Handbook on the Geographies of Innovation. Edward Elgar Publishing.

Asheim, B. T., Isaksen, A., \& Trippl, M. (2019). Advanced introduction to regional innovation systems.

Athukorala, P., \& Narayanan, S. (2018). Economic corridors and regional development: The Malaysian experience. World Development, 106, 1-14.

Awumbila, M. (2017). Drivers of migration and urbanization in Africa: Key trends and issues. International Migration, 7(8).

Azhari, A. R. (2019). Determinan pertumbuhan penyerapan tenaga kerja pada sektor industri manufaktur di Jawa Barat tahun 2005-2018. Universitas Siliwangi.

Budiyanti, E. (2016). Penguatan kembali industri manufaktur Indonesia. Majalah Info Singkat Ekonomi dan Kebijakan Publik, 8(12), 13-16.

Busch, J., Foxon, T. J., \& Taylor, P. G. (2018). Designing industrial strategy for a low carbon transformation. Environmental Innovation and Societal Transitions, 29, 114-125.

Cainelli, G., Ganau, R., \& Giunta, A. (2018). Spatial agglomeration, global value chains, and productivity. Microevidence from Italy and Spain. Economics Letters, 169, 43-46.

Carvalho, N., Chaim, O., Cazarini, E., \& Gerolamo, M. (2018). Manufacturing in the fourth industrial revolution: A positive prospect in sustainable manufacturing. Procedia Manufacturing, 21, 671-678.

Chandrasekhar, S., \& Sharma, A. (2015). Urbanization and spatial patterns of internal migration in India. Spatial Demography, 3(2), 63-89.

Davis, C., \& Hashimoto, K. (2018). Corporate tax policy and industry location with fully endogenous productivity growth. Economic Inquiry, 56(2), 1136-1148.

Day, L. H., \& Xia, M. (2019). Migration and urbanization in China. Routledge.

Dina, H. (2015). Analisis faktor-faktor yang mempengaruhi penyerapan tenaga kerja sektor industri manufaktur di Sumatera Barat. UPT. Perpustakaan.

Drucker, J., \& Feser, E. (2012). Regional industrial structure and agglomeration economies: An analysis of productivity in three manufacturing industries. Regional Science and Urban Economics, 42(1-2), 1-14.

Ermansyah, H., \& Mahi, B. R. (2019). Pengaruh pajak penghasilan badan terhadap permintaan tenaga kerja pada perusahaan manufaktur. Forum Ekonomi, 21(2), 143-153.

Fang, C., \& Yu, D. (2017). Urban agglomeration: An evolving concept of an emerging phenomenon. Landscape and Urban Planning, 162, 126-136.

Fatmawati, P., \& Utomo, Y. P. (2017). Analisis konsentrasi spasial industri manufaktur dengan tinjauan empiris di Kabupaten Sukoharjo. Universitas Muhammadiyah Surakarta.

Ginting, S. (2021). Faktor-faktor yang mempengaruhi penyerapan tenaga kerja sektor industri manufaktur di Kabupaten Malang tahun 2010-2018. Jurnal Ilmiah Mahasiswa FEB, 9(1).

Green, L. (2018). Migration, urbanization, and national development in Nigeria. In Modern Migrations in Western Africa (pp. 281-304). Routledge.

Guo, Q., \& He, C. (2017). Production space and regional industrial evolution in China. GeoJournal, 82(2), 379396. 
Jurnal Pendidikan Geografi:

Kajian, Teori, dan Praktik dalam Bidang Pendidikan dan Ilmu Geografi

27(1), 2022, 38-50

He, C., Mao, X., \& Zhu, X. (2018). Industrial dynamics and environmental performance in urban China. Journal of Cleaner Production, 195, 1512-1522.

Kennedy, P. S. J. (2017). Modul ekonomi mikro teori perilaku produsen.

Kornfeld, B. J., \& Kara, S. (2015). Industry-university collaboration in sustainable manufacturing. Procedia CIRP, 29, 8-12.

Kristianto, A. H., \& Nurcahyo, A. C. (2020). Potret kondisi perekonomian Indonesia.

Kumala, A. R., \& Rostiana, E. (2018). Faktor-faktor yang mempengaruhi investasi pada sektor industri manufaktur di Indonesia periode 2000-2017. Perpustakaan Fakultas Ekonomi dan Bisnis Unpas Bandung.

Kuncoro, M., \& Wahyuni, S. (2009). FDI impacts on industrial agglomeration: The case of Java, Indonesia. Journal of Asia Business Studies, 3(2), 65-78.

Kusumaningrum, E. (2017). Analisis penyerapan tenaga kerja sektor industri manufaktur di Indonesia. Universitas Gadjah Mada.

Latif, H. H., Gopalakrishnan, B., Nimbarte, A., \& Currie, K. (2017). Sustainability index development for manufacturing industry. Sustainable Energy Technologies and Assessments, 24, 82-95.

Lau, A. K. W., Lee, P. K. C., \& Cheng, T. C. E. (2018). An empirical taxonomy of corporate social responsibility in China's manufacturing industries. Journal of Cleaner Production, 188, 322-338.

Lau, P., Koo, T., \& Dwyer, L. (2017). Metrics to measure the geographic characteristics of tourism markets: An integrated approach based on Gini index decomposition. Tourism Management, 59, 171-181.

Liu, Y., Zhang, X., Kong, X., Wang, R., \& Chen, L. (2018). Identifying the relationship between urban land expansion and human activities in the Yangtze River Economic Belt, China. Applied Geography, 94, 163177.

Manyika, J., Lund, S., Chui, M., Bughin, J., Woetzel, J., Batra, P., ... Sanghvi, S. (2017). What the future of work will mean for jobs, skills, and wages. McKinsey Global Institute.

McCann, P., \& Van Oort, F. (2019). Theories of agglomeration and regional economic growth: A historical review. In Handbook of regional growth and development theories. Edward Elgar Publishing.

Meijer, A., \& Bolívar, M. P. R. (2016). Governing the smart city: A review of the literature on smart urban governance. International Review of Administrative Sciences, 82(2), 392-408.

Mori, T., \& Smith, T. E. (2015). On the spatial scale of industrial agglomerations. Journal of Urban Economics, $89,1-20$.

Muta'Ali, L. (2015). Teknik analisis regional untuk perencanaan wilayah, tata ruang dan lingkungan. Yogyakarta: Badan Penerbit Fakultas Geografi Universitas Gadjah Mada.

Nugroho, Y. D., \& Wahyuni, K. T. (2019). Aglomerasi dan dinamika industri manufaktur pada era revolusi industri 4.0 di koridor ekonomi Jawa. Seminar Nasional Official Statistics, 1, 687-699.

Pike, A., Rodríguez-Pose, A., \& Tomaney, J. (2017). Shifting horizons in local and regional development. Regional Studies, 51(1), 46-57.

Putri, A. S. P. (2019). Perkembangan industri knalpot di Kelurahan Purbalingga Lor, Kecamatan Purbalingga, Kabupaten Purbalingga tahun 1975-2008. Universitas Diponegoro.

Rakhmawati, A., \& Boedirochminarni, A. (2018). Analisis tingkat penyerapan tenaga kerja sektor industri di Kabupaten Gresik. Jurnal Ilmu Ekonomi JIE, 2(1), 74-82.

Rosyana, N., \& Soelistyo, A. (2020). Analisis penyerapan tenaga kerja pada industri manufaktur besar dan sedang pada tingkat kabupaten/kota di Provinsi Jawa Timur (2017-2019). Jurnal Ilmu Ekonomi JIE, $4(4), 723-731$.

Saputra, Y. T., \& Budiani, S. R. (2017). Kajian value chain pada industri knalpot di Kecamatan Purbalingga, Kabupaten Purbalingga, Jawa Tengah. Jurnal Bumi Indonesia, 6(3).

Setyoningrum, S. (2017). Faktor-faktor yang mempengaruhi Penanaman Modal Asing (PMA) langsung di Purbalingga. Fokus Bisnis: Media Pengkajian Manajemen dan Akuntansi, 16(2), 103-123.

Shao, S., Tian, Z., \& Yang, L. (2017). High speed rail and urban service industry agglomeration: Evidence from China's Yangtze River Delta region. Journal of Transport Geography, 64, 174-183. 


\section{Jurnal Pendidikan Geografi: \\ Kajian, Teori, dan Praktik dalam Bidang Pendidikan dan Ilmu Geografi}

27(1), 2022, 38-50

Sholihah, I. M., Syaparuddin, S., \& Nurhayani, N. (2017). Analisis investasi sektor industri manufaktur, pengaruhnya terhadap pertumbuhan ekonomi dan penyerapan tenaga kerja di Indonesia. Jurnal Paradigma Ekonomika, 12(1), 11-24.

Siregar, K. L. S. (2018). Analisis faktor-faktor yang mempengaruhi penyerapan tenaga kerja sektor industri manufaktur (besar dan sedang) Kabupaten Deli Serdang. Universitas Sumatera Utara.

Siregar, R. T., Rahmadana, M. F., Purba, B., Nainggolan, L. E., Sudarmanto, E., Nainggolan, P., ... Siagian, V. (2021). Ekonomi industri. Yayasan Kita Menulis.

Sosnovskikh, S. (2017). Peculiarities in the development of special economic zones and industrial parks in Russia. European Journal of Geography, 8(4), 82-102.

Sumarsono, S. (2009). Ekonomi sumber daya manusia teori dan kebijakan publik. Jogyakarta: Graha Ilmu.

Taddeo, R., Simboli, A., Ioppolo, G., \& Morgante, A. (2017). Industrial symbiosis, networking, and innovation: The potential role of innovation poles. Sustainability, 9(2), 169.

Wang, B. (2018). The future of manufacturing: A new perspective. Engineering, 4(5), 722-728.

Wang, J., Lin, Y., Glendinning, A., \& Xu, Y. (2018). Land-use changes and land policies evolution in China's urbanization processes. Land Use Policy, 75, 375-387.

Wang, X. R., Hui, E. C. M., \& Sun, J. X. (2017). Population migration, urbanization and housing prices: Evidence from the cities in China. Habitat International, 66, 49-56.

Wu, S., \& Yang, Z. (2018). Locating manufacturing industries by flow-capturing location model-case of Chinese steel industry. Transportation Research Part E: Logistics and Transportation Review, 112, 1-11.

Yogi, P. P. (2018). Analisis faktor-faktor yang mempengaruhi penyerapan tenaga kerja industri manufaktur besar dan sedang di provinsi Sumatera Barat. Universitas Andalas.

You, H., \& Bie, C. (2017). Creative class agglomeration across time and space in knowledge city: Determinants and their relative importance. Habitat International, 60, 91-100.

Zhen, F., Cao, Y., Qin, X., \& Wang, B. (2017). Delineation of an urban agglomeration boundary based on Sina Weibo microblog 'check-in'data: A case study of the Yangtze River Delta. Cities, 60, 180-191.

Zheng, Q., \& Lin, B. (2018). Impact of industrial agglomeration on energy efficiency in China's paper industry. Journal of Cleaner Production, 184, 1072-1080.

Zulkifli, Z. (2016). Faktor-faktor yang mempengaruhi penyerapan tenaga kerja di sektor industri manufaktur di Provinsi Sulawesi Selatan tahun 2004-2013. Universitas Islam Negeri Alauddin Makassar. 